\title{
The effectiveness of marketing communication through digital content for startup business (Case Study: Brandish beverage product)
}

\author{
Made Devicca Surya ${ }^{1}$, Firman Kurniawan ${ }^{2}$ \\ ${ }^{1}$ Department Management Communication, Universitas Indonesia, Jakarta, Indonesia \\ ${ }^{1}$ Department Management Communication, Universitas Indonesia, Jakarta, Indonesia \\ made.devicca@gmail.com (Made Devicca Surya)
}

\begin{abstract}
In today's modern era, food and beverages business has grown in Indonesia. The newly established business is called startup business. The number of startup businesses is increasing economic competition in their respective industries. No wonder many new businesses have failed in a short time period. Therefore, a strategy is needed before establishing a business. It should be noted that the strategy used will be implemented to a new business, so it is important to give attention to the awareness of potential consumers with marketing communication strategy. This research will look at the strategy that has been done from startup business company, Brandish, through retail or offline strategy with a rapidly growing strategy today, namely digital content. This research will use qualitative methods. It is important for the startup business owner to know where his business will go. If they think about long-term, then the company must think about a strategy that is far ahead, not just a temporary advantage only. Therefore, this research will focus on long-term company.
\end{abstract}

Keywords : : Startup Business, Digital Content, Marketing Communication

\section{Introduction}

Communication is one of the most important parts of human interaction. Communication is needed by humans to express opinions, solve problems or. Man as a social being, needs another human to survive. Communication is one way to ensure the fulfillment of human needs can be met. Communication between humans can be done between individuals, individuals with groups, even between groups of humans one with other human groups, both oral and non verbal.

When we have a business, of course in the process of buying and selling it can not be separated from communication. Communication happen between the seller to one buyer, the seller to a group of buyers, and so on. Existing communication in the buying and selling process such as product explanation, info about promo, what benefits can be obtained from the product, and etc.

The author raises a case study on a brand of beverage product, Brandish. Brandish is a start up business brand of milkshake that created by end-level undergraduate students who only run for six months. This business has a good strategy in terms of conventional and digital, although for six months it is a strategy that is often used is a conventional strategy, namely direct selling, distributing brochures, vouchers, and etc.

This time research wants to focus in digital strategy or in other words through social media. The strategy is to build consumer awareness through social media. Strategy through good marketing communication from social media is expected to help startup business to be able to survive in its industry competition in the long run.

\section{Method}

\subsection{Data source}

Sources of data used in this paper is a secondary data source that can support the search for answers to research questions and scholarship can be proved i.e. books, articles derived from various scientific journals and organization of the articles on the Internet site.

In addition, this study uses a research library which is a literature study program related to the issues raised either be books, papers that help to be made as all.

\subsection{Research approach}

The approach used in this paper is a qualitative approach with descriptive analysis. The type of qualitative approach is the type of data that can develop and expand. According Sugiyono (2005: 21) statement with descriptive method is a method used to describe or analyze a research results are not used to make a wider impulse.

Qualitative research is one of the research procedures that produces participant data, including the behavior of the observed person. A qualitative approach is expected to produce in-depth information about a particular topic of a particular individual, group, society, or organization in a particular context setting (Bogdan and Taylor, 1992).

\subsection{Data collection technique}

The data completion technique performed in this writing is by using literature and literature studies. Data collection methods used in qualitative research through interviews and observation. 


\subsection{Startup Business}

Today there are many people who feel the business opportunity is increasing. New entrepreneurs set up firms with profit thinking for direct stakeholders including customers, employees, suppliers, and investors (Lahdesmaki, 2005). There is an ongoing literature on sustainability and start-up with the concept of social entrepreneurship that emerged in the late 1990s and has recently become the focus of academic research (Hockerts and Wüstenhagen, 2010). Sustainability and entrepreneurship ultimately is the integration of social, environmental, and economic value creation.

Often business practices when linked to sustainability are seen as beneficial because new businesses have only a few established processes and organizational procedures later on. Therefore, there is an opportunity to develop sustainable business practices since the beginning of new ventures (Anderson and Leal, 1997). The founders of new business in general can also be aware of the opportunities offered by more sustainable business practices, and then build the practice into their business.

\subsection{Marketing Communications}

Promotion is any marketing activity in informing consumers about a product and to increase sales by attracting consumers to make purchasing decisions and using company products (Solomon, 2009). There are several elements that marketers can control in the delivery of messages through advertising, sales promotion, personal selling, community relations, and direct marketing. These elements are part of the promotion mix. Promotion Mix is the total communication activity consisting of advertising mix, personal selling, sales promotion, public relations, and direct marketing tools used to achieve advertising and marketing objectives (Kotler and Armstrong, 2012).

\subsection{Framework}

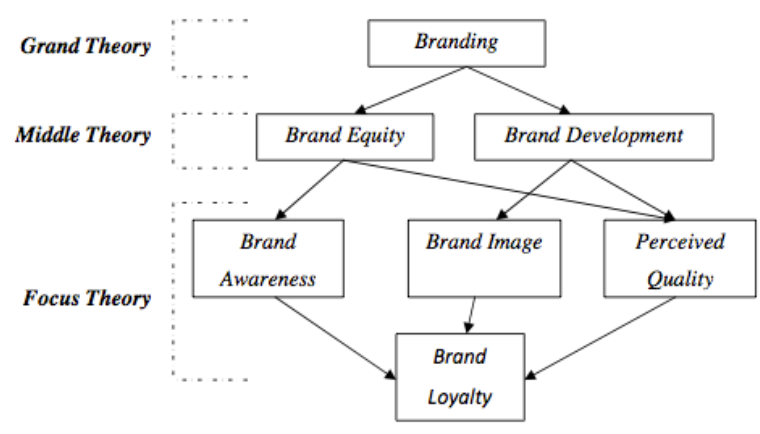

Figure 1. Framework of Theory Model

According to Kotler and Keller (2007: 70) brands are names, terms, signs, symbols, designs, or combinations of these which are intended to recognize the product or service of a person or a seller and to distinguish them from a competing product. Thus, the brand identifies the maker or seller of a product. While Branding is a collection of communication activities conducted by a company or a person in order to build and raise the brand (Maulana, 2010). Lindstrom says that, "Branding is a process of communication and relationship between the branding and the relationship between the brad Companies and consumers.

Branding strategy is needed by a company so that brands that want to appear in the community can be accepted and survive in the market. According to Gelder (2005), the branding strategy depends not only on the perceptions that exist in society but also depends on the instrument present in the brand and how the instrument is structured in brand management. Gelder added, there are three supporting elements in forming brand strategy, namely brand positioning, brand identity, and brand personality. Through the branding strategy mentioned, a company will be able to reach a stage called brand equity.

According to Kotler and Keller (2008: 261) based on the Aaker Model, Brand Equity has 5 components: perceived quality, brand loyalty, brand awareness, brand associations, and other exclusive brand assets. However, the fifth dimension of Aaker, another exclusive brand asset, is usually omitted in brand equity research because it is not directly related to the consumer in accordance with the research of Isabel Buil et al (2008):

\section{Brand Awareness}

The ability of the prospective buyer to recognize or remember that a brand is a member of a particular product category. This build is linked to the power of brand presence in the minds of consumers and is usually measured through brand recognition and recall under different circumstances.

Brand awareness becomes one of the important factors needed by business actors to strengthen their product brand. It can be said that the more consumers who remember a product brand, the greater the intensity of purchases they will make.

According to David A Aaker, brand awareness is defined to be 3 levels:

- Brand recognition is the lowest level where new consumers recognize a brand and still need tools to remember the brand.

- Brand recall, brand awareness comes to the minds of consumers once a particular brand is mentioned. In contrast to recognition that requires a tool, brand recall only requires repetition or re-mention to remember the product brand.

- Top of mind, the highest level in which a particular brand has dominated the minds of consumers, so in this level they do not need any reminders to be able to recognize a particular product brand. It takes a special promotional strategy to instill a strong enough product brand to get to the top of mind level.

\section{Brand Loyalty}

Customer attach to a brand. Brand loyalty can be conceptualized in several ways, for example, from a behavioral perspective, which emphasizes a thoroughgoing buying behavior or from an attitude perspective, which includes a commitment in terms of some unique value. 


\section{Brand Association}

Everything related to the memory of a brand. These associations can come from a variety of sources and vary according to the likes, strengths and uniqueness of the brand. The greatness of a brand association is its ability to shape positive attitudes, and strong perceptions and reasons to buy.

\section{4. $\quad$ Perceived Quality}

Costumer judge about the overall superiority of a product or superiority. It is not the quality of the purpose of the product but the subjective evaluation of the consumer depends on their perception.

The four elements are a unity of brand equity that will provide added value to a brand. But for this research, author will focus only for Brand Awareness, Brand Loyalty, and Perceived Quality.

\subsection{Social Media Platform}

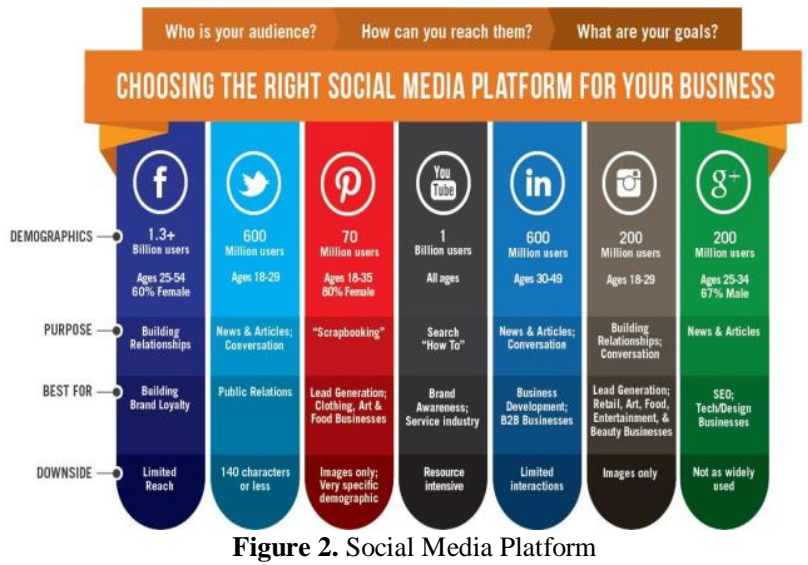

The platform above provides an overview of social media options that are suitable for use with businesses. Brandish is a beverage business whose target market is young people. Brandish is also a startup business that is not too familiar with the target market. Therefore, the selection of suitable social media based on the above platform is using Instagram where in terms of demographics, goals, and best to fit to be used for Brandish startup business.

\section{Result and Discussion}

The promotion mix strategy that Brandish use are Advertising, Sales Promotion (Sample, Voucher, and Discount), and Digital \& Social Media. For advertising and sales promotios is conventional strategy. They using paper for brochures, magazine, vouchers, and discount promotions. But, the weakness using paper are the effectiveness, cost, and reach. The effectiveness means that most people only see the paper just once. Some of them not interested to the promotion because they not giving their attention when they see the paper. Printing is also quite costly, and will create more expense that could be used for more efficient marketing activities. Marketing reach for paper advertising is also limited, as we will need efforts (manpower, time) to spread those papers.
For startup business, the level of marketing effectiveness is important. In addition to shorten marketing time, the cost that comes out effectively can affect the business. Today, the digital world like social media offers a place to promote time and cost effectively.

Social media actively used by Brandish is Instagram. Target follower Brandish first year as many as 1000 followers, mean average per month 83 followers. Currently, Instagram is a very effective social media to be used as a medium to communicate, informed and promoted products. Brandish has an Instagram account with an @ brandishoriginal_id ID that has 575 followers on June 2015 (5th month). Brandish more accessible to consumers, because only with 5 month, they can gain 100 followers per month in average. But currently (August 2017), followers are reduced to 364 because for approximately one year, Instagram account is not maintained for promotion.

Communication with social media users at least once a week through social media Instagram with reviews, promotions, special events and things that consumers love. Postings about the product, as well as the events that Brandish followed. The use of social media is needed by Brandish in preaching important information because it is practical to use and can disseminate information more broadly and quickly.

\subsection{Advertising}

Advertising that has been done Brandish in the form of distribution of brochures that are distributed directly to the target market around the location of selling and in universities located in areas such as Tangerang Swiss German University, Pelita Harapan University, Multimedia Nusantara University, and Prasetiya Mulya. Brochures distributed an average of 1000 pieces per month. Advertising through regional magazines around the place of selling has also been done, namely by doing an ad in Lippo Village magazine.

For the effectiveness, Brandish can post the advertising using social media, Instagram. Iklan yang di post bisa berupa promosi-promosi pada moment tertentu seperti valentine day, natal, lebaran, libur sekolah, dan sebagainya. Promosi seperti diskon, buy 1 get 1 , dan sebagainya juga dapat digunakan di Instagram. Para followers bisa menunjukan iklan tersebut di gerai Brandish dan langsung mendapatkan potongan harga, atau promosi lainnya yang sedang berlangsung. Pesan yang disampaikan melalui media social bisa efektif dari segi waktu, jangkauan, dan pengeluaran.

\subsection{Brand Endorsement}

Endorsers are advertising advocates or also known as ad stars who support the advertised product. Endorser is divided into two types: Typical Person Endorser, is utilizing some non-celebrities to convey a message about a product and Celebrity Endorser is a famous person who can influence others because of his achievements (Terence A. Shimp, 2003).

The popularity, image, and performance of the celebrity itself can further attract the target market to watch ads that can influence the target audience's perception of making a decision in making a purchase (McCracken, 2006).

Advertising is an important and influential element in instilling brand awarness to consumers, along with the 
physical characteristics and quality of products that follow a particular brand (Temporal \& Lee, 2010). The use of suitable and appropriate celebrities so that a good image of a celebrity can form a good image for the product brand (Byrne, Whitehead, and Breen, 2010).

Endorsers as advertising or promotional support can be used in social media, Instagram. They can post ads or promotions through instagramnya account and the followers of the endorser can immediately see in a short time because it spreads quickly.

Brandish has been using Instagram, but not until the endorsement of celebrities. They just ask the celebrities who come to take pictures with the product and then post in the account brandish itself. Promotion using celebrity accounts will be much more efficient because they have more followers than the startup business itself.

\subsection{Result}

\subsubsection{Brand Awareness}

Brand awareness to Brandish is not yet high. This is because Brandish is a new brand that has not been known to the wider community. Brandish runs its awareness strategy with advertising that is brochure distribution and sales promotion with samples, vouchers, and discounts. Another thing used is social media. From six months the business was run, in the 5th month (June 2015) followers Instagram Brandish reached 575 followers. Currently (August 2017), followers are reduced to 364 . This is because for two years, social media is not on the run and indeed the business is not running.

When Brandish is still actively selling, the strategy for brand awareness is to follow the bazaar that is expected to increase instagram followers. Followers do increase, but if compared using endorsement, the increase will be much more effective. The fee used for bazaar promotion can be transferred to the endorsement cost. When following the bazaar, it is not just the rent of the place that is issued, but other support costs such as pickup cars, additional electricity, and so forth will be the burden of spending.

Brandish is a startup business that already has some loyal customers. When considered at the level of brand awareness, Brandish can actually be at all three levels (Recognition, Recall, and Top of Mind). This is because there are consumers who are new to know Brandish brand as a startup business, even until there are consumers who are already loyal although only limited.

As a startup business, Brandish has a huge opportunity because in just a few months they already have consumers who are already at the top of mind stage of brand awareness of the brand. So, for consumers and prospective consumers who are still on the stage of recognition and recall need to be considered again strategy so that they are more aware of a brand. The strategy can be in the form of promotion in social media, Instagram, which is post by endorsement.

\subsubsection{Perceived Quality}

The most important information of a product's quality according to the consumer is the consistency of the product quality. The thing to do is maintain the consistency of product quality by using SOP detail and firm. Brandish sells its products using SOP where the portion of a serving must match the same menu.

\subsubsection{Brand Loyalty}

According to previous research, consumers are less loyal to the milkshake brand purchased because the result is in doubt with their loyalty to the milkshake brand. So, there is a Brandish opportunity to attract Brandish consumers. Consumer loyalty to a brand when they make a purchase or purchase intention and like the product or service. Therefore, Brandish who offer good quality on milkshake should be able to make loyal fans to the brand.

\subsection{Discussion}

Brandish as a startup business has applied marketing communication through advertising, sales promotion, and digital content. Brandish's strategy is well done at startup business. Brandish, however, does not maximize its strategy through marketing communication. It is seen from Brandish company that only stands for one year. Brandish no longer runs his business due to poor planning for pioneering companies.

If you look at the marketing strategy, for a firm, Brandish takes a lot of advertising expenditure on magazines or brochures. For potential customers who are not aware of the brand, magazine ads or brochures will not be directly attached to their minds.

The next marketing strategy through sales promotion provides good feedback for the startup business. Brandish provides product samples for potential customers to experience new product variants. If they do not know the taste of the drink, then will not interest to buy. Vouchers and discounts given are also appropriate to the target consumers i.e. students. For students, getting vouchers and discounts makes them interested to buy the product. At first they just wanted to try. So there is no harm in buying a product with a voucher or discount it.

Brandish also implements marketing communications strategy with digital content. Digital content is applied Brandish through social media Instagram. Brandish promotion news is distributed to potential customers through the social media.

Through the above theories, it seems that the implementation for the Brandish startup business is still lacking in its brand awareness. Not because of the short selling time problem, but the strategy for potential customers to know that brand should be in priority. Previous research gives results in purchasing products (purchase intention), consumers must be aware first. They should know there are products that are sold with the brand. Therefore, in this case brand awereness is a very important starting point for startup business. With prospective customers aware of the brands they are offering, they are sure to buy, and they judge the quality of their products well, the prospective customer will become a loyal consumer of the brand. This high quality product will also create the image of the brand that will be captured by consumers as a brand image. 
Prospective consumers say aware of brand awareness is divided into three. First, the recognition that they are aware of someone to make a purchase. Second, remember where consumers remember the brand of a product without any bantam to bring up the brand name. Third, to the thought that consumers immediately think of a brand or brand it is the main brand that is in the minds of consumers.

With these three categories of brand awareness, an easy first step is through Word of Mouth (WOM). Through WOM, one can do a brand story telling with a new product. WOM. In addition to WOM, they can also do brand story telling through social media, for example with social media, Instagram. Starting from the visual message you want to disseminate, invite followers to participate in the product, and keep followers by giving rewards for them. Other strategies may use endorsements to post the message. These endorsements are expected to help the promotion because of the number of their followers, and information can be shared in a short time. This strategy takes short times compared to the bazaar for brand awereness.

Other common problem facing business startup is budgeting. Therefore, the allocation of funds should be appropriate to minimize expenditure, but still use an effective and efficient strategy. Digital content in the modern era is the right strategy for startup business because not a few of the people who already depend on digital. If the startup business has the right strategy in digital content, then consumers will be aware, even loyal to the product brand.

\section{Conclusion}

For a new business or startup business, if the company wants to survive among its competitors, then they need to consider the aspect of sustainability of the company in the future.

The initial strategy to be considered is how producers think of marketing strategies to get to potential customers. Marketing strategy that starts from brand awareness where the company must be strong in terms of branding, so that potential consumers aware of the brand. If we talk business in the long term, then the company must be able to make consumers loyal to the brand. The way is that potential customers should be aware of the brand, then make them curious and after that they will do a purchase, and if the product or service offered in line with the quality they expected, then the consumer will be loyal to the brand.

Marketing strategy in this modern era has developed and uses digital. One of the promotion is using social media. Therefore, brand awareness using social media is good for both startup business. By following the flow of the times, the company either new or old must be able to adjust it.

\section{REFERENCES}

[1] Firmansari, Fica (2015). Konsep Sustainability dalam Pelaporan Corporate Social Responsibility. Jember: Unibersitas Jember.
[2] Galpin, T., Jouflas, G. and Gasta, M. (2014), "Leading the sustainable organization at Vail Resorts", Journal of Business Strategy, Vol. 35 No. 6, pp. 19-30.

[3] Galpin, Timothy dan Hebard, Julia (2015). Sustainability in start-up ventures: what founders say versus what they do. USA: Emerald Group Publishing Limited.

[4] Galpin, T.J., Whittington, J.L. and Bell, R.G. (2012), Leading the Sustainable Organization: Development, Implementation, and Assessment, Routledge, New York, NY.

[5] Gelder, S.V. (2005). Global brand strategy. London: Kogan Page

[6] Kotler dan Keller, 2007. Manajemen Pemasaran, Edisi 12, Jilid 1, PT.Indeks, Jakarta.

[7] Kotler, Philip dan Kevin Lane Keller, 2008. Manajemen Pemasaran, Jilid 1, Penerbit Erlangga. Jakarta.

[8] Pace, R. Wayne \& Faules, Don F. (1994). Organizational)Communication. Third Edition. New Jersey: Prentice Hall, Englewood Clifs. 